\title{
Body weight components and meat quality of hair sheep fed diets containing different carbohydrate sources associated with urea
}

\author{
Felipe J.S. da Silva ${ }^{1}$, Kelly C. dos Santos², Adriana Guim², Ana M.D. Cabral ${ }^{3}$, Michel do V. Maciel ${ }^{4}$, \\ Andreza G. de O. Nascimento ${ }^{2}$, Dorgival M. de Lima-Júnior ${ }^{5 *}$, and Francisco F.R. de Carvalho ${ }^{2}$
}

\begin{abstract}
${ }^{1}$ Universidade Federal da Paraíba, Rodovia BR 079, km 12, 58.397-000, Areia, Paraíba, Brasil.
${ }^{2}$ Universidade Federal Rural de Pernambuco, Dom Manoel de Medeiros Street, s/n, Dois Irmãos, 52171-900, Recife, Pernambuco, Brasil. ${ }^{3}$ Universidade Federal Rural de Pernambuco, Unidade Acadêmica de Serra Talhada, Rodovia BR 232, 56909-000, Serra Talhada, Pernambuco, Brasil.

${ }^{4}$ Universidade Federal do Amazonas, Campus Parintins, 69152-470, Parintins, Amazonas, Brasil.

${ }^{5}$ Universidade Federal de Alagoas, Campus Arapiraca, Manoel Severino Barbosa Street, s/n, Bom Sucesso, Arapiraca, Alagoas, 57309-005, Brasil. .Corresponding author (juniorzootec@yahoo.com.br).
\end{abstract}

Received: 17 January 2020. Accepted: 11 April 2020; doi:10.4067/S0718-58392020000300361

\begin{abstract}
In semi-arid zones, feedlots are considered a tool to minimize the impacts of seasonal forage on the production of sheep meat in the tropics. However, the use of alternative tropical ingredients as substitutes for corn (Zea mays L.) and soybean (Glycine max [L.] Merr.) meal in formulations of confined sheep diets is recurrent. The aim of this study was to evaluate the effect of diets containing corn and soybean meal (CS), corn (CU), cassava (Manihot esculenta Crantz) root (CRU) or spineless cactus (Opuntia ficus-indica [L.] Mill., SCU) associated with urea on the performance, carcass characteristics and meat quality of confined lambs. Forty non-castrated Santa Inês sheep with average age of $150 \mathrm{~d}$ and average initial weight of $22.6 \pm 2.3 \mathrm{~kg}$ were confined in individual pens for $76 \mathrm{~d}$ and slaughtered. The diets effects were contrasted by Tukey test. Empty body weight was different among the treatments $(\mathrm{P}<0.05)$ and was $27.3,25.3,23.0$ and $21.1 \mathrm{~kg}$ for the animals fed CS, CU, CRU and SCU, respectively. CS diet presented higher cold carcass weights while SCU diet presented lower cold carcass weights $(\mathrm{P}<0.05)(11.37 \mathrm{~kg})$ and higher cooling losses. Luminosity, yellow color intensity and meat moisture content were higher $(\mathrm{P}<0.05)$ in SCU than CS. Liver, skin and internal fat weights were similar $(\mathrm{P}>0.05)$ in $\mathrm{CU}$ and $\mathrm{CRU}$, but higher $(\mathrm{P}<0.05)$ than SCU. The replacement of corn and soybean meal for different carbohydrate sources associated with urea reduces the body weight components in confined sheep.
\end{abstract}

Key words: Cassava, non-carcass components, non-protein nitrogen, spineless cactus.

\section{INTRODUCTION}

In semi-arid zones, there is a seasonal variation in pasturable phytomass available for small ruminant herds, which has a severe impact on animal production. Therefore, feedlots are considered a tool to minimize the impacts of seasonal forage on the production of sheep meat in the tropics.

However, corn and soybean cultivation, which are the main components of confined animal diets, is hampered by climatic conditions in arid and semi-arid zones. Therefore, the use of alternative tropical ingredients as substitutes for corn and soybean meal in formulations of confined sheep diets is recurrent. Santos et al. (2015), for example, observed that corn can be completely replaced by cassava peel associated with urea in sheep diet. On the other hand, despite being forage rich in moisture, Pinto et al. (2011) recommended the replacement of 75\% of corn ground with spineless cactus in confined lambs diet. 
Due to its low cost and high availability, urea is historically regarded as a substitute ingredient for soybean meal in formulations for ruminants (Patra, 2015). However, the efficiency of the conversion of non-protein $\mathrm{N}$ in microbial protein depends on the association with fermentable carbohydrates sources in the rumen (Estrada-Angulo et al., 2016).

Thus, the use of synchronous tropical carbohydrate sources to urea may improve microbial protein synthesis and animal performance. The aim of this study was to evaluate the effect of diets containing corn, cassava root or spineless cactus associated with urea, on the body weight components and meat quality of confined sheep.

\section{MATERIALS AND METHODS}

The study was performed according to ethical standards and approved by the Ethics Committee for Animal Use (CEUA) of the Federal Rural University of Pernambuco (UFRPE), Brazil - CEUA License 0512/2015.

The experiment was carried out in Recife ( $8^{\circ} 04^{\prime} 03^{\prime \prime}$ S, 34 35'00" W; 4 m a.s.l.), Brazil. Forty non-castrated Santa Inês sheep were confined with average age of $150 \mathrm{~d}$ and average weight of $22.58 \pm 2.28 \mathrm{~kg}$. The experiment lasted $76 \mathrm{~d}(20$ $\mathrm{d}$ adaptation and $56 \mathrm{~d}$ data collection). The animals were confined in individual pens of $1.0 \mathrm{~m} \times 1.6 \mathrm{~m}$, with feeder and drinker, in a closed feedlot shed. Before the beginning of the experiment, the animals were submitted to ectoparasites and endoparasites control and vaccinated against clostridiosis.

The experiment was performed in a completely randomized design with four treatments with 10 replicates each. The treatments were the following: a control (corn [Zea mays L.] + soybean [Glycine max (L.) Merr.] meal) and three different carbohydrate sources associated to urea: corn + urea, cassava (Manihot esculenta Crantz) root + urea, and spineless cactus (Opuntia ficus-indica [L.] Mill.) + urea. The diets were formulated to be isonitrogenated in order to meet nutritional requirements of sheep weighing up to $25 \mathrm{~kg}$ body weight, aiming at an average daily gain of $200 \mathrm{~g} \mathrm{~d}^{-1}$ (NRC, 2007). Experimental diets were offered as a complete mixture and in a forage:concentrate ratio of 58:42. 'Tifton 85' Bermuda grass (Cynodon dactylon [L.] Pers.) hay was used as forage. The concentrate varied according to the treatments: corn and soybean meal (CSM), corn and urea (CU), cassava root and urea (CRU), and spineless cactus and urea (SCU) (Table 1).

Table 1. Proportion of ingredients and chemical-bromatological composition of diets.

\begin{tabular}{|c|c|c|c|c|}
\hline Ingredients $\left(\mathrm{g} \mathrm{kg}^{-1}\right)$ & Corn + soybean meal & Corn + urea & Cassava root + urea & Spineless cactus + urea \\
\hline \multicolumn{5}{|l|}{ Proportion } \\
\hline Tifton hay ${ }^{2}$ & 580.0 & 581.0 & 580.0 & 580.0 \\
\hline Soybean meal ${ }^{2}$ & 170.0 & 0.0 & 0.0 & 0.0 \\
\hline Ground corn ${ }^{2}$ & 240.0 & 385.0 & 0.0 & 0.0 \\
\hline Cassava root ${ }^{2}$ & 0.0 & 0.0 & 377.0 & 0.0 \\
\hline Spineless cactus ${ }^{2}$ & 0.0 & 0.0 & 0.0 & 379.0 \\
\hline Urea:SA ${ }^{2}$ & 0.0 & 24.0 & 33.0 & 31.0 \\
\hline Mineral $\mathrm{mix}^{2}$ & 7.0 & 7.0 & 7.0 & 7.0 \\
\hline Calcitic limestone $^{2}$ & 3.0 & 3.0 & 3.0 & 3.0 \\
\hline \multicolumn{5}{|l|}{ Chemical composition } \\
\hline Dry matter ${ }^{1}$ & 903.5 & 907.9 & 904.2 & 217.6 \\
\hline Organic matter ${ }^{2}$ & 929.3 & 938.3 & 936.7 & 896.4 \\
\hline Mineral matter ${ }^{2}$ & 70.7 & 61.7 & 63.3 & 103.6 \\
\hline Crude protein ${ }^{2}$ & 154.0 & 149.1 & 146.2 & 147.9 \\
\hline Ethereal extract ${ }^{2}$ & 24.3 & 29.2 & 9.6 & 13.1 \\
\hline Neutral detergent fiber ${ }^{2,3}$ & 458.2 & 457.5 & 425.3 & 500.0 \\
\hline Acid detergent fiber ${ }^{2}$ & 247.1 & 235.6 & 229.9 & 269.3 \\
\hline Lignin acid detergent ${ }^{4}$ & 20.2 & 20.2 & 20.0 & 21.2 \\
\hline Total carbohydrates ${ }^{2}$ & 750.9 & 798.3 & 832.3 & 783.0 \\
\hline Non-fibrous carbohydrates ${ }^{2,3}$ & 292.8 & 340.0 & 406.5 & 282.8 \\
\hline Total digestible nutrients ${ }^{2}$ & 693.5 & 689.9 & 665.8 & 609.1 \\
\hline
\end{tabular}

${ }^{1} \mathrm{~g} \mathrm{~kg}^{-1}$ natural matter.

${ }^{2} \mathrm{~g} \mathrm{~kg}^{-1}$ dry matter.

${ }^{3}$ Corrected for ash and protein.

${ }^{4}$ Corrected for ash. 
'Tifton 85' hay was crushed in forage machine generating particles of $5 \mathrm{~cm}$. Spineless cactus was crushed in machine generating particles of $3 \mathrm{~cm}$. Cassava root was crushed in a machine and dried in the sun until reaching $14 \%$ moisture. The concentrate was ground in $0.5 \mathrm{~cm}$ sieves. Diets were provided twice a day, 60\% at 08:00 h and 40\% at 16:00 h. The diet amount was adjusted every $2 \mathrm{~d}$, based on the animal voluntary intake with estimated leftovers of $15 \%$.

Dry matter (DM), mineral matter (MM), crude protein (CP) and ethereal extract (EE) were determined according to AOAC (1995). Determinations of neutral detergent fiber (NDF) and acid detergent fiber (ADF) were performed according to Van Soest et al. (1991). The equation proposed by Sniffen et al. (1992) was used for the estimation of total carbohydrates (TCH), the equation proposed by Detmann and Valadares Filho (2010) for non-fibrous carbohydrate (NSF), and the equation described by Weiss (1999) for total digestible nutrients (TDN).

The animals were weighed at the beginning and at the end of the experimental period. After $76 \mathrm{~d}$, the animals were submitted to a 16-h solids fastening before slaughter. Before slaughter, the animals were weighed to obtain body weight at slaughter (BWS) and weight loss due fasting (WLF). The animals were stunned by the penetrative percussive method with the help of a captive dart gun, suspended by the hind limbs through ropes and bled by splitting the carotid arteries and jugular veins. Blood was collected and weighed. After bleeding, manual skinning and evisceration were performed and all components of thoracic, abdominal and pelvic cavity were weighed (Brasil, 2000).

Then, the remaining components of animal body weight were removed (head, feet, tail and reproductive system) to determine hot carcass weight (HCW). Subsequently, gallbladder, bladder and gastrointestinal tract were weighed and then washed and reweighed again to determine empty body weight (EBW). The carcasses were taken to cold chamber with an average $4{ }^{\circ} \mathrm{C}$. Hydrogen potential reading was performed $(\mathrm{pH} 0 \mathrm{~h}$ ) and they remained for $24 \mathrm{~h}$ cooling, suspended by hooks through the tendon of gastrocnemius muscle. After this cooling period, they were weighed to obtain cold carcass weight $(\mathrm{CCW})$ and another $\mathrm{pH}$ reading was performed $(\mathrm{pH} 24 \mathrm{~h}) ; \mathrm{pH}$ readings were obtained in the Semimembranosus muscle, with aid of a $\mathrm{pH}$ meter.

Cooling losses (CL) and cold carcass yield (CCY) were determined by the following equations:

$$
C L(\%)=(H C W-C C W / H C W) \times 100 \text {, and } C C Y(\%)=(C C W / B W A) \times 100
$$

Carcass compactness index $\left(\mathrm{CCI} \mathrm{kg} \mathrm{cm}{ }^{-1}=\right.$ cold carcass weight/internal carcass length) and leg compactness index (LCI $\mathrm{cm} \mathrm{cm}^{-1}=$ croup width/leg length)

were calculated from the establishment of the relationships between cold carcass weight, internal carcass length, croup width and leg length. In addition, the carcass conformation was determined with a score from 1 to 5 (poor to excellent); carcass fatness with a score from 1 to 5 (fat absence to excessive fat) with a scale of 0.25 ; and the amount of pelvic-renal fat with a score from 1 to 3, in which one (1) is classified as low, two (2) normal and three (3) as a lot of fat (Cezar and Sousa, 2007).

Each carcass was sagittally divided and the left half was sectioned into six anatomical regions that made the following cuts: neck, shoulder, rib, loin, leg and foreshank. Carcass relative regional composition was determined by the relative calculation of each cut by the reconstituted weight of the left half carcass.

A cut was performed between the $12^{\text {th }}$ and $13^{\text {th }}$ ribs of the left half carcass to expose the Longissimus dorsi muscle to obtain loin eye area (LEA) using a digital planimeter (Digiplan model, Gebrüder HAFF, Pfronten, Germany). Backfat thickness measurement was performed with a digital caliper in millimeters in the L. dorsi muscle (Cezar and Sousa, 2007).

For qualitative analysis of the meat, left half of the loin (Longissimus lumborum) of each animal was used, which were vacuum packed and frozen at $-18{ }^{\circ} \mathrm{C}$, and subsequently thawed at $4{ }^{\circ} \mathrm{C}$. Determinations of meat color, cooking losses and shear force were performed according to the methodology described by Abreu et al. (2019).

The color evaluation was performed after standardization of the cuts with at least $15 \mathrm{~mm}$ thickness, followed by exposure to air for $30 \mathrm{~min}$. Readings were performed with the aid of a colorimeter, where three measurements were performed at different points of the muscle, using the mean values for color representation.

To evaluate cooking losses, samples were previously thawed for $24 \mathrm{~h}$ under refrigeration $\left(4^{\circ} \mathrm{C}\right)$, and cut into $2.5 \mathrm{~cm}$ thick steaks. Then, steaks were roasted in a preheated oven at $200{ }^{\circ} \mathrm{C}$, until reaching $70{ }^{\circ} \mathrm{C}$ in the geometric center, and the temperature was monitored through a specialized thermometer for cooking meat (AcuRite, Chaney Instrument Co., Lake Geneva, Wisconsin). The losses during cooking were calculated by the weight difference of the samples before and after cooking and expressed as a percentage.

For the determination of the shear force of the remaining cooked samples of the cooking loss determination procedure, at least two cylindrical samples were removed, with a perforating tube puncher of $1.27 \mathrm{~cm}$ diameter, in the longitudinal 
direction of the fiber. The force needed to cross-section each cylinder was measured with Warner-Bratzler shear force equipment with a load cell of $25 \mathrm{kgf}$ and speed of $20 \mathrm{~cm} \mathrm{~min}^{-1}$. The mean shear forces of each cylinder were used to represent the hardness value of each sample.

Water holding capacity (WHC) was determined according to the methodology proposed by Sierra (1973), in which muscle samples with approximately $300 \mathrm{mg}$ were placed between two pieces of previously weighed filter paper (W1) and pressed for $5 \mathrm{~min}$, using a weight of $3.4 \mathrm{~kg}$. After pressing, muscle samples were removed and the papers were again weighed (W2). WHC was calculated according to the equation:

$$
W H C(\%)=(W 2-W 1) / S \times 100
$$

where $S$ is the weight of the sample.

Samples of the left L. lumborum muscle were taken from each animal, crushed in blender until obtaining a homogeneous paste and were then freeze-dried for moisture determination (Method nr 925.04), crude protein (Method nr 981.10), ether extract (Method nr 935.38) and ash (Method nr 938.08), using the protocols described by AOAC (1995).

Qualitative data were submitted to ANOVA and the quantitative variables were submitted to covariance analysis, with live weight as covariable, using SAEG software (Universidade Federal de Viçosa, Viçosa, Minas Gerais, Brazil) at 5\% significance. When significant differences were detected among treatments for the different variables, they were compared by Tukey test at the same level of significance.

\section{RESULTS}

Body weight at slaughter (BWS) of animals fed corn and soybean meal diet (CS) and corn with urea (CU) did not differ among themselves $(\mathrm{P}>0.05)$ (Table 2). However, BWS of animals fed CU and cassava root with urea (CRU) did not differ among themselves $(\mathrm{P}>0.05)$, and showed an average of $31.5 \mathrm{~kg}$. The animals fed spineless cactus with urea (SCU) showed the lowest BWS $(\mathrm{P}<0.05)$.

Weight losses due fasting (WLF) did not differ $(\mathrm{P}>0.05)$ among animals that consumed CU or CRU diets, with averages of $2.94 \%$ and $3.36 \%$, respectively (Table 2). However, animals fed SCU diet, showed higher fasting losses $(\mathrm{P}<$ 0.05 ) and presented average of $6.33 \%$.

The cold carcass weight (CCW) followed the empty body weight (EBW) behavior and presented averages of 15.2, $13.8,12.6$ and $11.4 \mathrm{~kg}$ for CS, CU, CRU and SCU, respectively. The difference between CS and CU treatments for CCW was only $1.4 \mathrm{~kg}$. Cooling loss (CL) of the carcasses of animals fed SCU was higher $(\mathrm{P}<0.05)$ than the animals fed CS diet, with average of 6.96\%. However, CL did not differ $(\mathrm{P}>0.05)$ among diets with corn and soybean meal and corn and urea. Backfat thickness was not influenced by diets $(\mathrm{P}>0.05)$.

Shoulder and leg weights followed EBW and CCW behavior and were higher in CS diet when compared to diets containing corn, cassava and spineless cactus (Table 3). Proportionally, shoulder and leg represented $53.3 \%$ of the CCW. Animals fed CS, CU or CRU diets did not differ $(\mathrm{P}>0.05)$ conformation, carcass fatness and perirenal fat (Table 4$)$.

Table 2. Energy intake and carcass characteristics of Santa Inês sheep fed diets containing different sources of carbohydrates associated with urea.

\begin{tabular}{|c|c|c|c|c|c|c|}
\hline & $\begin{array}{c}\text { Corn + soybean } \\
\text { meal }\end{array}$ & Corn + urea & $\begin{array}{l}\text { Cassava } \\
\text { root + urea }\end{array}$ & $\begin{array}{c}\text { Spineless } \\
\text { cactus + urea }\end{array}$ & $\mathrm{P}$ & SEM \\
\hline TDN intake, $\mathrm{kg} \mathrm{d}^{-1}$ & $0.778 \mathrm{a}$ & $0.806 \mathrm{a}$ & $0.731 \mathrm{ab}$ & $0.590 \mathrm{~b}$ & 0.0037 & 0.02 \\
\hline Body weight at slaughter, $\mathrm{kg}$ & $34.29 \mathrm{a}$ & $32.45 \mathrm{ab}$ & $30.66 \mathrm{~b}$ & $27.89 \mathrm{c}$ & $<0.001$ & 0.24 \\
\hline Weight loss due fasting, $\%$ & $3.49 \mathrm{~b}$ & $2.94 \mathrm{~b}$ & $3.36 \mathrm{~b}$ & $6.33 \mathrm{a}$ & $<0.001$ & 0.24 \\
\hline Empty body weight, kg & $27.31 \mathrm{a}$ & $25.31 \mathrm{~b}$ & $23.00 \mathrm{c}$ & $21.11 \mathrm{~d}$ & $<0.001$ & 0.15 \\
\hline Hot carcass weight, $\mathrm{kg}$ & $15.96 \mathrm{a}$ & $14.54 \mathrm{~b}$ & $13.30 \mathrm{c}$ & $12.22 \mathrm{~d}$ & $<0.001$ & 0.11 \\
\hline Cold carcass weight, $\mathrm{kg}$ & $15.21 \mathrm{a}$ & $13.82 \mathrm{~b}$ & $12.59 \mathrm{c}$ & $11.37 \mathrm{~d}$ & $<0.001$ & 0.09 \\
\hline Cold carcass yield, \% & $44.27 \mathrm{a}$ & 42.56ab & $40.97 \mathrm{bc}$ & $40.53 \mathrm{c}$ & $<0.001$ & 0.26 \\
\hline Cooling losses, \% & $4.70 \mathrm{~b}$ & $4.96 \mathrm{~b}$ & $5.34 \mathrm{ab}$ & $6.96 \mathrm{a}$ & 0.039 & 0.25 \\
\hline Loin eye area, $\mathrm{cm}^{2}$ & $12.10 \mathrm{a}$ & $10.93 \mathrm{ab}$ & $11.27 \mathrm{ab}$ & $9.90 \mathrm{~b}$ & 0.043 & 0.25 \\
\hline Backfat thickness, mm & 1.04 & 0.94 & 0.85 & 0.96 & 0.302 & 0.04 \\
\hline Initial $\mathrm{pH}$ & 6.75 & 6.81 & 6.90 & 6.69 & 0.125 & 0.03 \\
\hline Final $\mathrm{pH}$ & 5.44 & 5.35 & 5.35 & 5.40 & 0.117 & 0.01 \\
\hline
\end{tabular}

Means followed by different letters in the same row differ significantly from each other by Tukey test at $5 \%$ probability. TDN: Total digestible nutrients; P: probability; SEM: standard error of the mean. 
Table 3. Weight and yield of carcass cuts of Santa Inês sheep fed diets containing different sources of carbohydrates associated with urea.

\begin{tabular}{|c|c|c|c|c|c|c|}
\hline & $\begin{array}{c}\text { Corn + soybean } \\
\text { meal }\end{array}$ & Corn + urea & $\begin{array}{l}\text { Cassava } \\
\text { root + urea }\end{array}$ & $\begin{array}{c}\text { Spineless } \\
\text { cactus + urea }\end{array}$ & $\mathrm{P}$ & SEM \\
\hline \multicolumn{7}{|c|}{ Weight (kg) } \\
\hline Neck & $0.74 \mathrm{a}$ & $0.61 \mathrm{~b}$ & $0.55 b c$ & $0.51 \mathrm{c}$ & $<0.001$ & 0.01 \\
\hline Shoulder & $1.37 \mathrm{a}$ & $1.24 \mathrm{~b}$ & $1.15 \mathrm{c}$ & $1.06 \mathrm{~d}$ & $<0.001$ & 0.01 \\
\hline Rib & $1.39 \mathrm{a}$ & $1.21 \mathrm{~b}$ & $1.19 \mathrm{~b}$ & $1.01 \mathrm{c}$ & $<0.001$ & 0.02 \\
\hline Foreshank & $0.67 \mathrm{a}$ & $0.64 \mathrm{a}$ & $0.60 \mathrm{a}$ & $0.51 \mathrm{~b}$ & $<0.001$ & 0.01 \\
\hline Loin & $0.62 \mathrm{a}$ & $0.55 \mathrm{ab}$ & $0.51 b c$ & $0.46 \mathrm{c}$ & $<0.001$ & 0.01 \\
\hline Leg & $2.50 \mathrm{a}$ & $2.33 b$ & $2.14 \mathrm{c}$ & $1.92 \mathrm{~d}$ & $<0.001$ & 0.02 \\
\hline \multicolumn{7}{|c|}{ Yield (\%) } \\
\hline Neck & $10.09 a$ & $9.25 \mathrm{ab}$ & $8.86 \mathrm{~b}$ & $9.25 \mathrm{ab}$ & 0.021 & 0.13 \\
\hline Shoulder & 18.81 & 18.91 & 18.82 & 19.39 & 0.955 & 0.14 \\
\hline Rib & 19.02 & 18.43 & 19.26 & 18.47 & 0.992 & 0.20 \\
\hline Foreshank & 9.24 & 9.73 & 9.86 & 9.33 & 0.306 & 0.13 \\
\hline Loin & 8.49 & 8.34 & 8.30 & 8.32 & 0.083 & 0.14 \\
\hline Leg & 34.34 & 35.34 & 34.90 & 35.24 & 0.284 & 0.19 \\
\hline
\end{tabular}

Means followed by different letters in the same row differ significantly from each other by Tukey test at 5\% probability.

P: Probability; SEM: standard error of the mean.

The luminosity $\left(\mathrm{L}^{*}\right)$ and yellow color intensity $\left(\mathrm{b}^{*}\right)$ of the meat of animals fed the diet based on spineless cactus and urea were higher $(\mathrm{P}<0.05)$ than those fed the control diet (Table 5). Water holding capacity (WHC), cooking losses $(\mathrm{CL})$ and shear force (SF) parameters were not affected by the different treatments. However, the moisture content of the meat of the animals that were fed the diet on the basis of spineless cactus was higher $(\mathrm{P}<0.05)$ than that of the other treatments, while the protein content of the meat was higher in animals fed cassava root and urea (Table 6).

Rumen-reticulum, liver and internal fat weights did not differ $(\mathrm{P}>0.05)$ between CS, CU and CRU diets. However, they were lighter $(\mathrm{P}<0.05)$ in animals fed SCU diet (Table 7).

Table 4. Morphometric measurements and subjective evaluations of Santa Inês sheep carcass fed diets containing different sources of carbohydrates associated with urea.

\begin{tabular}{|c|c|c|c|c|c|c|}
\hline & $\begin{array}{c}\text { Corn + soybean } \\
\text { meal }\end{array}$ & Corn + urea & $\begin{array}{l}\text { Cassava } \\
\text { root + urea }\end{array}$ & $\begin{array}{c}\text { Spineless } \\
\text { cactus + urea }\end{array}$ & $\mathrm{P}$ & SEM \\
\hline Internal length, $\mathrm{cm}$ & 62.80 & 63.44 & 61.89 & 61.36 & 0.317 & 0.42 \\
\hline Thorax perimeter, $\mathrm{cm}$ & $65.26 \mathrm{a}$ & $65.89 \mathrm{a}$ & $64.74 \mathrm{ab}$ & $62.36 \mathrm{~b}$ & 0.006 & 0.34 \\
\hline Carcass compactness index, $\mathrm{kg} \mathrm{cm}^{-1}$ & $0.243 \mathrm{a}$ & $0.217 \mathrm{~b}$ & $0.203 b$ & $0.185 \mathrm{c}$ & $<0.001$ & 0.01 \\
\hline Leg compactness index, $\mathrm{kg} \mathrm{cm}^{-1}$ & 0.559 & 0.549 & 0.545 & 0.519 & 0.390 & 0.01 \\
\hline Conformation (1-5) & $2.74 \mathrm{a}$ & $2.55 \mathrm{a}$ & $2.46 \mathrm{a}$ & $1.92 \mathrm{~b}$ & $<0.001$ & 0.06 \\
\hline Fatness (1-5) & $2.46 \mathrm{a}$ & $2.31 \mathrm{ab}$ & $2.29 \mathrm{ab}$ & $1.81 \mathrm{~b}$ & 0.011 & 0.07 \\
\hline Perirenal fat (1-3) & $2.36 \mathrm{a}$ & $2.28 \mathrm{a}$ & $1.85 \mathrm{ab}$ & $1.53 \mathrm{~b}$ & $<0.001$ & 0.07 \\
\hline
\end{tabular}

Means followed by different letters in the same row differ significantly from each other by Tukey test at $5 \%$ probability. P: Probability; SEM: standard error of the mean.

Table 5. Characteristics of Santa Inês sheep meat fed diets containing different carbohydrate sources associated with urea.

\begin{tabular}{lcccccc}
\hline & $\begin{array}{c}\text { Corn + soybean } \\
\text { meal }\end{array}$ & Corn + urea & $\begin{array}{c}\text { Cassava } \\
\text { root + urea }\end{array}$ & $\begin{array}{c}\text { Spineless } \\
\text { cactus + urea }\end{array}$ & P & SEM \\
\hline Luminosity $\left(\mathrm{L}^{*}\right)$ & $35.42 \mathrm{~b}$ & $34.83 \mathrm{~b}$ & $35.87 \mathrm{ab}$ & $37.54 \mathrm{a}$ & $<0.001$ & 0.25 \\
Red color intensity $\left(\mathrm{a}^{*}\right)$ & 14.33 & 14.24 & 14.03 & 14.54 & 0.4956 & 0.12 \\
Yellow color intensity $\left(\mathrm{b}^{*}\right)$ & $6.49 \mathrm{~b}$ & $7.16 \mathrm{a}$ & $6.58 \mathrm{~b}$ & $7.22 \mathrm{a}$ & $<0.001$ & 0.08 \\
Water holding capacity, \% & 36.39 & 40.53 & 36.74 & 35.66 & 0.3664 & 1.05 \\
Cooking losses, \% & 37.94 & 36.85 & 34.82 & 38.36 & 0.6981 & 1.13 \\
Shear force, kgf & 1.86 & 1.89 & 1.76 & 1.90 & 0.2658 & 0.03 \\
\hline
\end{tabular}

Means followed by different letters in the same row differ significantly from each other by Tukey test at 5\% probability.

P: Probability; SEM: standard error of the mean. 
Table 6. Chemical composition of sheep meat fed diets containing different carbohydrate sources associated with urea.

\begin{tabular}{lcccccc}
\hline & $\begin{array}{c}\text { Corn + soybean } \\
\text { meal }\end{array}$ & Corn + urea & $\begin{array}{c}\text { Cassava } \\
\text { root + urea }\end{array}$ & $\begin{array}{c}\text { Spineless } \\
\text { cactus + urea }\end{array}$ & P & SEM \\
\hline Moisture, \% & $76.07 \mathrm{~b}$ & $76.14 \mathrm{~b}$ & $76.22 \mathrm{~b}$ & $78.14 \mathrm{a}$ & $<0.001$ & 0.16 \\
Protein, \% & $19.08 \mathrm{~b}$ & $19.59 \mathrm{ab}$ & $20.39 \mathrm{a}$ & $19.61 \mathrm{ab}$ & 0.001 & 0.12 \\
Fat, \% & 1.76 & 1.64 & 1.57 & 1.35 & 0.1560 & 0.07 \\
Ashes, \% & 1.33 & 1.33 & 1.39 & 1.22 & 0.2464 & 0.03 \\
\hline
\end{tabular}

Means followed by different letters in the same row differ significantly from each other by Tukey test at $5 \%$ probability.

P: Probability; SEM: standard error of the mean.

Table 7. Weight and yield of non-carcass components of Santa Inês sheep fed diets containing different carbohydrate sources associated with urea.

\begin{tabular}{|c|c|c|c|c|c|c|}
\hline & $\begin{array}{c}\text { Corn + soybean } \\
\text { meal }\end{array}$ & Corn + urea & $\begin{array}{l}\text { Cassava } \\
\text { root + urea }\end{array}$ & $\begin{array}{c}\text { Spineless } \\
\text { cactus + urea }\end{array}$ & $\mathrm{P}$ & SEM \\
\hline \multicolumn{7}{|c|}{ Non-carcass components weight (kg) } \\
\hline Rumen & 0.67 & 0.63 & 0.60 & 0.60 & 0.0953 & 0.01 \\
\hline Reticulum & 0.11 & 0.13 & 0.12 & 0.12 & 0.5170 & 0.01 \\
\hline Small intestine & $0.64 \mathrm{a}$ & $0.61 \mathrm{a}$ & $0.50 \mathrm{~b}$ & $0.52 \mathrm{~b}$ & $<0.001$ & 0.01 \\
\hline Lungs & $0.36 \mathrm{a}$ & $0.34 \mathrm{a}$ & $0.30 \mathrm{~b}$ & $0.28 \mathrm{~b}$ & $<0.001$ & 0.01 \\
\hline Kidneys & $0.09 \mathrm{a}$ & $0.08 \mathrm{ab}$ & $0.07 \mathrm{~b}$ & $0.08 \mathrm{ab}$ & 0.0112 & 0.01 \\
\hline Liver & $0.51 \mathrm{a}$ & $0.48 \mathrm{ab}$ & $0.42 \mathrm{bc}$ & $0.37 \mathrm{c}$ & $<0.001$ & 0.01 \\
\hline Blood & $1.20 \mathrm{a}$ & $1.14 \mathrm{ab}$ & $1.06 \mathrm{ab}$ & $1.01 \mathrm{~b}$ & 0.0247 & 0.02 \\
\hline Skin & $2.43 \mathrm{a}$ & $2.10 \mathrm{~b}$ & $2.00 \mathrm{~b}$ & $1.76 \mathrm{c}$ & $<0.001$ & 0.02 \\
\hline Total fat & $0.97 \mathrm{a}$ & $0.92 \mathrm{a}$ & $0.71 \mathrm{ab}$ & $0.61 \mathrm{~b}$ & 0.0049 & 0.038 \\
\hline CGIT & 6.98 & 7.15 & 7.66 & 6.77 & 0.2179 & 0.15 \\
\hline \multicolumn{7}{|c|}{ Non-carcass component yield (\%) } \\
\hline Rumen & $2.46 \mathrm{~b}$ & $2.49 \mathrm{~b}$ & $2.62 \mathrm{ab}$ & $2.90 \mathrm{a}$ & 0.0055 & 0.044 \\
\hline Reticulum & $0.47 \mathrm{~b}$ & $0.50 \mathrm{ab}$ & $0.51 \mathrm{ab}$ & $0.59 \mathrm{a}$ & 0.0064 & 0.014 \\
\hline Small intestine & 2.36 & 2.44 & 2.18 & 2.53 & 0.0599 & 0.044 \\
\hline Lungs & 1.31 & 1.37 & 1.32 & 1.34 & 0.3320 & 0.021 \\
\hline Kidneys & 0.33 & 0.34 & 0.31 & 0.36 & 0.2656 & 0.008 \\
\hline Liver & 1.88 & 1.89 & 1.84 & 1.74 & 0.3937 & 0.032 \\
\hline Blood & 4.40 & 4.50 & 4.63 & 4.78 & 0.8590 & 0.086 \\
\hline Skin & $8.88 \mathrm{a}$ & $8.29 b$ & $8.72 \mathrm{ab}$ & $8.31 \mathrm{~b}$ & 0.0125 & 0.070 \\
\hline Total fat & 3.52 & 3.61 & 3.06 & 2.82 & 0.1907 & 0.144 \\
\hline CGIT $^{1}$ & $20.43 c$ & $22.15 b c$ & $25.02 \mathrm{a}$ & $24.54 \mathrm{ab}$ & $<0.001$ & 0.357 \\
\hline
\end{tabular}

Means followed by different letters in the same row differ significantly from each other by Tukey test at 5\% probability.

P: Probability; SEM: standard error of the mean.

CGIT: Contents of the gastrointestinal tract.

${ }^{1}$ CGIT/body weight at slaughter.

\section{DISCUSSION}

Body weight at slaughter (BWS) was similar between CS and CU and both were higher than slaughter weight of animals fed SCU. The lower consumption of TDN observed in animals fed SCU diet probably led to a lower weight at slaughter of this group. Fasting losses in animals fed SCU represented 6\%, the approximately double of that observed in the other diets. Spineless cactus is rich in water and presents a high passage rate of organic matter (more than $10 \% \mathrm{~h}^{-1}$ ) (Santos et al., 2018). Those characteristics contribute to a greater emptying of gastrointestinal tract during fasting.

Despite the similarity in TDN intake between CS and CU diets, empty body weight (EBW) was lower $(\mathrm{P}<0.05)$ for animals fed corn with urea. In that case, deficiency of degradable protein and branched-chain amino acids in corn compared to soybean meal may have limited the synthesis of microbial protein in rumen and reduced the amount of net protein to gain. Animals fed SCU diet showed the lowest EBW among the diets, with average of $21.11 \mathrm{~kg}$. TDN intake in this diet is equivalent to $75.8 \%$ of the intake in the control diet. However, body weight at slaughter (BWS) corresponded to $81.3 \%$ for the same diet. This indicates that spineless cactus with urea has great potential in sheep diets. 
Cold carcass weight (CCW) followed EBW behavior and was higher for CS diet than CU, CRU and SCU. According to Silva et al. (2016) CCW has a high and positive correlation (0.88) with EBW in confined Santa Inês sheep. It was observed that carcasses obtained from animals fed SCU diets were less heavy and presented higher cooling losses (CL). This corroborates with the study of Jacob and Hopkins et al. (2014), who observed that lighter beef carcasses suffer greater cooling losses.

There was no difference among treatments for backfat thickness (BFT), with average of $0.96 \mathrm{~mm}$. According to Sousa et al. (2019), regarding CCW, the adipose tissue is late. In the present study, Santa Inês sheep, a late maturity breed, was used with BWS ranging from 27.89 to $34.29 \mathrm{~kg}$, and with an average age of $220 \mathrm{~d}$, when the deposition of adipose tissue is still not very expressive in the carcass. Santa Inês breed has internal fat as the primary site of adipose deposition, not the backfat (Oliveira et al., 2018). Neck, rib, foreshank and loin weights did not differ between CU and CRU diets, but were higher in CS. For Santos-Cruz et al. (2009), sheep commercial cuts follow the growth pattern of CCW, with members presenting an early growth.

Carcass compactness index (CCI) was higher for CS. Leg compactness index (LCI) and carcass fatness were similar $(\mathrm{P}>0.05)$ between CS, CU and CRU diets. Since CCI, LCI and conformation are positively correlated with the degree of carcass muscularity, these results show that through the use of ingredients that are easy to obtain and produce in tropical areas, such as cassava, it is possible to produce carcasses with the same muscularity of animals fed traditional ingredients such as corn with urea. Thus, CS diet presented compact and higher cold carcass weights.

The higher luminosity of sheep meat fed a diet based on spineless cactus and urea is possibly caused by the higher moisture found in animal meat, because the greater the presence of water in this tissue, the greater the reflection of light and the value of $\mathrm{L}^{*}$. The yellow color intensity $\left(\mathrm{b}^{*}\right)$ of animal meat fed the diets based on corn plus urea and spineless cactus and urea $(7.16$ and 7.22$)$ was higher $(\mathrm{P}<0.05)$ compared to those fed with the control diets and cassava root plus urea (6.49 and 6.58). This difference is due to carotenoid pigments present in the spineless cactus (Slimen et al., 2016) and corn (lutein and zeaxanthin), which were deposited in the meat, contributing to the increase in the value of $b^{*}$.

The similarity observed for the $\mathrm{pH}$ values of the carcass of the animals also influenced the absence of difference for the parameters of water holding capacity (WHC) and cooking losses (CL) that were not affected by the different treatments (Table 5). The mean values found were $37.33 \%$ for WHC and 36.99\% for CL.

The higher moisture content observed in the meat sheep fed spineless cactus and urea is probably due to the metabolic moment distinct from the animals, evidenced here by the lower PCF, referring to the low dry matter deposition in the body composition of the animals. We proposed that the animals fed a spineless cactus had not yet filled intramuscular adipocytes and therefore had more space for muscle fibers (water-rich tissue), resulting in greater humidity (Wood et al., 2008; Lage et al., 2014).

Although differences in the protein content of sheep meat are more accentuated between different genotypes or muscles (Komprda et al., 2012; Mortimer et al., 2014), the diet based on cassava root plus urea provided a protein increase $(\mathrm{P}<0.05)$ in the meat of animals that were fed with it, in relation to those that were fed the control diet. It is likely that the timing between the fermentation rates of CRU have provided an increase in ruminal microbial protein synthesis, promoting greater amino acid flow in the small intestine and better muscle protein synthesis when compared to control animals. The meat of animals that were fed the diets based on CU and SCU showed no difference $(\mathrm{P}>0.05)$ of protein content between themselves and even for the other treatments. However, there was no effect of treatment for the fat and ash contents of animal meat. The fat content of the meat of the animals of the present study are below average for the same genotype and similar slaughter weight ( Ribeiro et al., 2017; Abreu et al., 2019).

There was no difference for rumen and reticulum weight. However, when compared to EBW, rumen and reticulum yields were higher for animals fed SCU diet than CU diet. The higher amount of NDF in this diet possibly contributes to a greater rumen development. Clauss et al. (2016) report that ruminants gastric compartments adjust in size to the digesta volume. Small intestine of animals that received CS and CU diets was heavier. Due to the low ruminal solubility of corn starch and greater amount of grain in corn diet, there was possibly a greater flow of starch into the small intestine of animals that received this cereal, causing a trophic effect on the intestinal mucosa.

Liver and kidney weights of CU diet did not differ from animals fed with CRU. Liver and kidneys are priority organs in sheep metabolism and grow at a faster rate than animal's EBW (Garcia et al., 2014). Thus, the similarity in liver and kidney weight can be explained by the same TDN consumption of diets with corn and cassava root. Blood weight was 
lower for animals that received the SCU diet. However, it did not differ between CU and CRU diets. Blood has many uses in pharmaceutical and food industry and is a byproduct which can be value aggregated, like the skin (Toldrá et al., 2016). Thus, CS and CU diet presented higher non-carcass components weights.

\section{CONCLUSIONS}

Urea associated with a carbohydrate source -cassava root, corn or spineless cactus- does not replace soybean meal in confined sheep diets. The replacement of corn and soybean meal for different carbohydrate sources associated with urea reduces the body weight components and increase the meat moisture in confined sheep.

\section{ACKNOWLEDGEMENTS}

The authors thank the Coordination for the Improvement of Higher Education Personnel (CAPES) for the granting of a postgraduate scholarship and the National Council for Scientific and Technological Development (CNPq) for funding this research.

\section{REFERENCES}

Abreu, K.S.F., Véras, A.S.C., Ferreira, M.A., Madruga, M.S., Maciel, M.I.S., Félix, S.C.R., et al. 2019. Quality of meat from sheep fed diets containing spineless cactus (Nopalea cochenillifera Salm Dyck). Meat Science 148:229-235.

AOAC. 1995. Official methods of analysis of AOAC. 16 $6^{\text {th }}$ ed. Association of Official Agricultural Chemists (AOAC) International, Arlington, Virginia, USA.

Brasil. 2000. Ministério da Agricultura. Instrução Normativa n³, de 07 de janeiro de 2000. Regulamento técnico de métodos de insensibilização para o abate humanitário de animais de açougue. S.D.A./M.A.A. p. 14-16. 24 de janeiro de 2000. Seção I. Diário Oficial da União, Brasília, Brasil.

Cezar, M.F., e Sousa, W.H. 2007. Carcaças ovinas e caprinas- Obtenção, avaliação e classificação. Editora Agropecuária Tropical, Uberaba, Minas Gerais, Brasil.

Clauss, M., Stewart, M., Price, E., Peilon, A., Savage, T., Van Ekris, I., et al. 2016. The effect of feed intake on digesta passage, digestive organ fill and mass, and digesta dry matter content in sheep (Ovis aries): Flexibility in digestion but not in water reabsorption. Small Ruminant Research 138:12-19.

Detmann, E., and Valadares Filho, S.C. 2010. On the estimation of non-fibrous carbohydrates in feeds and diets. Arquivo Brasileiro de Medicina Veterinária e Zootecnia 62:980-984.

Estrada-Angulo, A., López-Soto, M.A., Rivera-Méndez, C.R., Castro, B.I., Ríos, F.G., Dávila-Ramos, H., et al. 2016. Effects of combining feed grade urea and a slow-release urea product on performance, dietary energetics and carcass characteristics of feedlot lambs fed finishing diets with different starch to acid detergent fiber ratios. Asian-Australasian Journal of Animal Science 29:1725-1733.

Garcia, I.F., Alvarenga, T.I.R.C., Perez, J.R.O., Almeida, A.K., Gallo, S.B., Pereira, I.G., et al. 2014. Allometric growth of noncarcass components in crossed lambs. Ciência Rural 44:1229-1235.

Jacob, R.H., and Hopkins, D.L. 2014. Techniques to reduce the temperature of beef muscle early in the post mortem period - a review. Animal Production Science 54:482-493.

Komprda, T., Kuchtík, J., Jarosová, A., Dracková, E., Zemánek, L., and Filipcík, B. 2012. Meat quality characteristics of lambs of three organically raised breeds. Meat Science 91:499-505.

Lage, J.F., Berchielli, T.T., San Vito, E., Silva, R.A., Ribeiro, A.F., Reis, R.A., et al. 2014. Fatty acid profile, carcass and meat quality traits of young Nellore bulls fed crude glycerin replacing energy sources in the concentrate. Meat Science 96:1158-1164.

Mortimer, S.I., van der Werf, J.H.J., Jacob, R.H., Hopkins, D.L., Pannier, L., Pearce, K.L., et al. 2014. Genetic parameters for meat quality traits of Australian lamb meat. Meat Science 96:1016-1024.

NRC. 2007. Nutrient requirements of small ruminants: Sheep, goats, cervids, and New World camelids. National Research Council (NRC), National Academy of Science, Washington, D.C., USA.

Oliveira, J.P.F., Ferreira, M.A., Alves, A.M.S.V., Melo, A.C.C., Andrade, I.B., Urbano, S.A., et al. 2018. Carcass characteristics of lambs fed spineless cactus as a replacement for sugarcane. Asian-Australasian Journal of Animal Science 31:529-536.

Patra, A.K. 2015. Urea/ammonia metabolism in the rumen and toxicity in ruminants. p. 329-341. In Puniya, A., Singh, R., and Kamra, D. (eds.) Rumen microbiology: From evolution to revolution. Springer, New Delhi, India. 
Pinto, T.F., Costa, R.G., Medeiros, N.A., Medeiros, G.R., Azevedo, O.S., Oliveira, R.L., et al. 2011. Use of cactus pear (Opuntia ficus indica Mill) replacing corn on carcass characteristics and non-carcass components in Santa Inês lambs. Revista Brasileira de Zootecnia 40:1333-1338.

Ribeiro, J.S., Santos, L.L., De Lima Júnior, D.M., Mariz, T.M.A., Ladeira, M.M., Azevedo, P.S., et al. 2017. Spineless cactus associated with Tifton hay or sugarcane bagasse may replace corn silage in sheep diets. Tropical Animal Health and Production 49:995-1000.

Santos, V.L.F., Ferreira, M.A., Siqueira, M.C.B., Melo, T.T.B., Silva, J.L., Andrade, I.B., et al. 2015. Rumen parameters of sheep fed cassava peel as a replacement for corn. Small Ruminant Research 133:88-92.

Santos, R.D., Neves, A.L.A., Santos, D.C., Pereira, L.G.R., Gonçalves, L.C., Ferreira, A.L., et al. 2018. Divergence in nutrient concentration, in vitro degradation and gas production potential of spineless cactus genotypes selected for insect resistance. Journal of Agricultural Science 156:450-456.

Santos-Cruz, C.L., Pérez, J.R.O., Muniz, J.A., Cruz, C.A.C., e Almeida T.R.V. 2009. Desenvolvimento dos componentes do peso vivo de cordeiros Santa Inês e Bergamácia abatidos em diferentes pesos. Revista Brasileira de Zootecnia 38:923-932.

Sierra, I. 1973. Aportaciones al estudio del cruce Blanco Belga $\times$ Landrace: caracteres productivos, calidad de la canal y calidad de la carne. Revista del Instituto de Economía y Producciones Ganaderas del Ebro 16:43.

Silva, D.L.S., Braga, A.P., Lima Júnior, D.M., Costa, W.P., Amâncio, A.V.F., e Braga, Z.C.A.C. 2016. Efeito de inclusões crescentes de torta de girassol em dietas de cordeiros em confinamento: desempenho e características de carcaça. Acta Veterinaria Brasilica 10:216-223.

Slimen, I.B., Najar, T., and Abderrabba, M. 2016. Opuntia ficus-indica as a source of bioactive and nutritional phytochemicals. Journal of Food and Nutrition Sciences 4:162-169.

Sniffen, C.J., O'Connor, J.D., Van Soest, P.J., Fox, D.G., and Russell, J.B. 1992. A net carbohydrate and protein system for evaluating cattle diets. II. Carbohydrate and protein availability. Journal of Animal Science 70:3562-3577.

Sousa, M.A.P., Lima, A.C.S., Araújo, J.C., Guimarães, C.M.C., Joele, M.R.S.P., Borges, I., et al. 2019. Tissue composition and allometric growth of carcass of lambs Santa Inês and crossbreed with breed Dorper. Tropical Animal Health and Production 51:1903-1908.

Toldrá, F., Mora, L., and Reig, M. 2016. New insights into meat by-product utilization. Meat Science 120:54-59.

Van Soest, P.J., Robertson, J.B., and Lewis, B.A. 1991. Methods for dietary fiber, neutral detergent fiber, and nonstarch polysaccharides in relation to animal nutrition. Journal of Dairy Science 74:3583-3597.

Weiss, W.P. 1999. Energy prediction equations for ruminant feeds. p. 176-185. In Cornell Nutrition Conference Feed Manufactures. Proceedings. Cornell University, Ithaca, New York, USA.

Wood, J.D., Enser, M., Fisher, A.V., Nute, G.R., Sheard, P.R., Richardson, R.I., et al. 2008. Fat deposition, fatty acid composition and meat quality: A review. Meat Science 78:343-358. 